\title{
Stemming Kata Berimbuhan Tidak Baku Bahasa Indonesia Menggunakan Algoritma Jaro-Winkler Distance
}

\author{
Stemming Non-Formal Affix Word Indonesian Language \\ Using Jaro-Winkler Distance Algorithm \\ Mudawil Qulub*1, Ema Utami ${ }^{2}$, Andi Sunyoto ${ }^{3}$ \\ 1,2,3 Magister Informatika, Universitas AMIKOM Yogyakarta \\ E-mail: *1'mudawil.qulub@students.amikom.ac.id, ${ }^{2}$ ema.u@amikom.ac.id, \\ 3andi@amikom.ac.id
}

\begin{abstract}
Abstrak
Bahasa merupakan media untuk mengekspresikan keinginan, gagasan, dan perasaan. Dalam kaitannya dengan bahasa indonesia, bahasa dapat mencerminkan prilaku dalam sebuah masyarakat. Bahasa indonesia dapat digunakan secara formal maupun non-formal. Bahasa nonformal berbentuk kata tidak baku yang biasanya digunakan dalam komentar atau posting dalam media sosial. Salah satu contoh kata tidak baku adalah "nemenin" yang kata formalnya "menemani" dan kata dasarnya adalah "teman". Dalam penelitian ini akan dilakukan pengujian akurasi algoritma Jaro-Winkler distance dalam mengubah kata imbuhan tidak baku menjadi bentuk dasarnya, proses ini disebut dengan stemming. Penelitian ini menggunakan data sebanyak 60 kata berimbuhan tidak baku. Hasil pengujian menunjukkan tingkat akurasi algoritma JaroWinkler sebesar 85\% atau 51 kata berhasil di-stemming (3 overstemming, 6 unstemming, 0 understemming).
\end{abstract}

Kata Kunci — Kata Imbuhan Tidak Baku, Stemming, Jaro-Winkler Distance

\begin{abstract}
Language that represents the media to attract interest, regulate, and feel. In reversing it with Indonesian, language can reflect behavior in a society. Indonesian can be used formally or informally. Non-formal language in the form of non-formal words used in comments or posts on social media. One example of a non-formal word is "accompanying" the formal word "accompany" and the basic word is "friend". In this research, the Jaro-Winkler algorithm will be tested the distance in changing non-formal affix words into a form of interaction, this process is called stemming. This research uses data as many as 60 words that are not standardized. The test results show the level of testing of the Jaro-Winkler algorithm is $85 \%$ or 51 words successfully stemmed (3 overstemming, 6 unstemming, 0 understemming).
\end{abstract}

Keywords - Non-Formal Affix, Stemming, Jaro-Winkler Distance 


\section{PENDAHULUAN}

Bahasa digunakan oleh seseorang untuk mengekspresikan keinginan, gagasan, dan perasaan. Selain sebagai media ekspresi personal, bahasa juga bisa menjadi media ekspresi masyarakat. Dalam kaitannya dengan bahasa indonesia, pemakaian bahasa oleh seseorang atau sekelompok orang dapat mencerminkan prilaku kebahasaan masyarakat indonesia. Pemakaian bahasa Indonesia yang baik dan benar ditentukan oleh ragam pemakaian dengan situasi dan kondisi serta bidang kehidupan tertentu [1]. Bahasa Idonesia dapat digunakan secara formal dan non-formal. Bahasa non-formal bisanya digunakan disaat kondisi sedang santai seperti saat berkomentar di sosial media, posting, dan chatting. Salah satu contohnya adalah "Lu udah nemenin emak belanja", pada kalimat ini ditemukan kata "nemenin" yang bentuk formalnya adalah "menemani" dengan kata dasar "teman". Twitter merupakan media sosial yang menyediakan banyak sekali data yang mudah didapat, dimana masyarakat indonesia kebanyakan menggunakan kata tidak baku dalam setiap komentar dan post mereka [2].

Stemming adalah proses mengubah kata menjadi kata dasarnya. Stemming biasanya digunakan pada IR (Information Retrieval), peningkatan performa pencarian, dan deteksi plagiarism, dan sistem pemrosesan bahasa alami untuk meningkatkan kinerjanya. Stemming dapat meningkatkan teks karena proses ini akan menggabungkan kata-kata yang memiliki kata dasar yang sama. Jika kata-kata memiliki kata dasar yang sama, maka mereka diaggap memiliki kemiripan makna [3]. Stemming pada kata tidak baku dapat digunakan pada chat bot, sentiment analysis, dan pemrosesan teks yang lainnya [4].

Penelitian tentang stemming bahasa indonesia dengan menggunakan algoritma Flexibility Affix Classification dan membandingkannya dengan algoritma stemming Nazief \& Adriani. Penelitian ini melakukan percobaan dengan menggunakan data bahasa indonesia sebanyak 1.704 teks dokumen dengan 255.182 tokens, dan 3648 kata stemmed. Penelitian ini menghasilkan pendekatan kinerja yang lebih baik dari confix-stripping dari Nazief \& Adriani. Kelebihan dari penelitian ini adalah cara mudah dalam menambahkan imbuhan dengan algoritma Flexibility Affix Classification dalam stemming bahasa indonesia. Kekurangan penelitian algoritma ini yaitu tidak bisa melakukan stemming kata reduplikasi bahasa Indonesia [5].

Penelitian lainnya tentang stemming kata tidak baku bahasa indonesia dengan memodifikasi algoritma Non-Formal Affix menggunakan pendekatan Levenstein distance. Pada penelitian ini menggunkan data kata tidak baku sebanyak 60 kata, menghasilkan tingkat akurasi sebesar 96,6\% atau 58 kata berhasil di-stemming [2].

Penelitian ketiga yang relevan yaitu penelitian algoritma Nazief \& Adriani digunakan sebagai retrieval system dalam Al Hadith dalam bahasa indonesia oleh Atqia Aulia, Dewi Khairani, dan Nashruel Hakim [6]. Pada penelitian ini stemming dengan menerapkan algoritma Nazief \& Adriani pada bahasa permrograman PHP untuk menampilkan hasil pencarian hadith. Analisi hasil uji menujukkan bahwa repositori menggunkan stemming menghasilkan penarikan dengan skor sempuna 1 dan presisi 0,961. Ini menunjukkan bahwa repositori dapat mengembalikan sejumlah besar dokumen yang relevan.

Berdasarkan uraian diatas, pada penelitian ini peneliti mengusulkan penelitian dengan menggunakan algoritma Jaro-Winkler distance untuk proses stemming kata berimbuhan tidak baku dalam bahasa indonesia. 


\section{METODE PENELITIAN}

\subsection{Tahapan Penelitian}

Penelitian ini berfokus pada pengujian akurasi algoritma Jaro-Winkler distance dalam melakukan stemming kata tidak baku pada bahasa indonesia. Tahapan penelitian dapat dilihat pada Gambar 1.

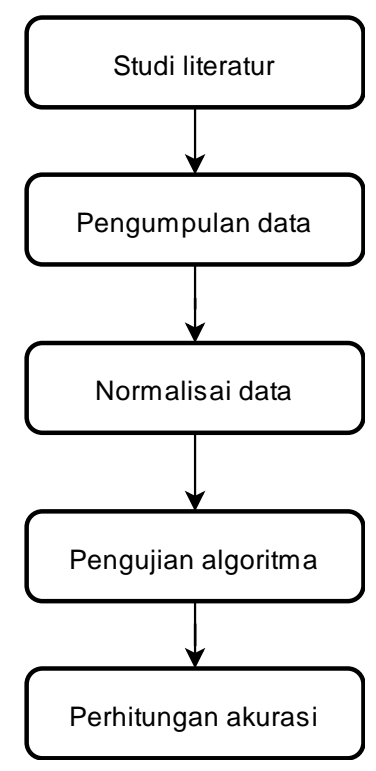

Gambar 1. Tahapan Penelitian

a. Studi literature dilakukan untuk memperdalam pengetahuan serta mencari landasan teori mengenai struktur imbuhan bahasa indonesia, imbuhan tidak baku bahasa indonesia, stemming, dan algoritma Jaro-Winkler distance.

b. Data pada penelitian jurnal ini merupakan data yang sekunder yang diambil dari penelitian sebelumnya yang berjudul "Optimalisasi stemming Kata Berimbuhan Tidak Baku Pada Bahasa Indonesia Dengan Levenshtein Distance” [2].

c. Normalisasi data bertujuan untuk membuat data lebih kompetibel ketika diterapkan pada bahasa pemrograman.

d. Pengujian dilakukan dengna data yang sudah didapatkan pada aplikasi stemming yang sudah diterapkan algoritma Jaro-Winkler distance.

e. Perhitungan akurasi dilakukan dengan menggunakan metode confusion matrix.

\subsection{Struktur Imbuhan Bahasa Indonesia}

Imbuhan bahasa indonesia terdiri dari prefix (awalan), infiks, suffix (akhiran), dan confix. Imbuhan (affix) adalah morpheme yang ditambahkan ke kata untuk membuat kata baru. Prefix (awalan) adalah imbuhan yang ditambahkan di awal kata. Infix adalah imbuhan yang dimasukkan kedalam kata. Suffix (akhiran) adalah imbuhan yang ditambahkan di akhiran kata. Sementara itu, confix adalah kombinasi di awalan dan akhiran kata. Pada bahasa indonesia, imbuhan dapat ditambahkan pada kata kerja, kata sifat, atau kata benda [5]. Gambar 2 mengilustrasikan konsep imbuhan dalam bahasa indonesia. 
Citec Journal, Vol. 5, No. 4, Agustus 2018 - Oktober 2018

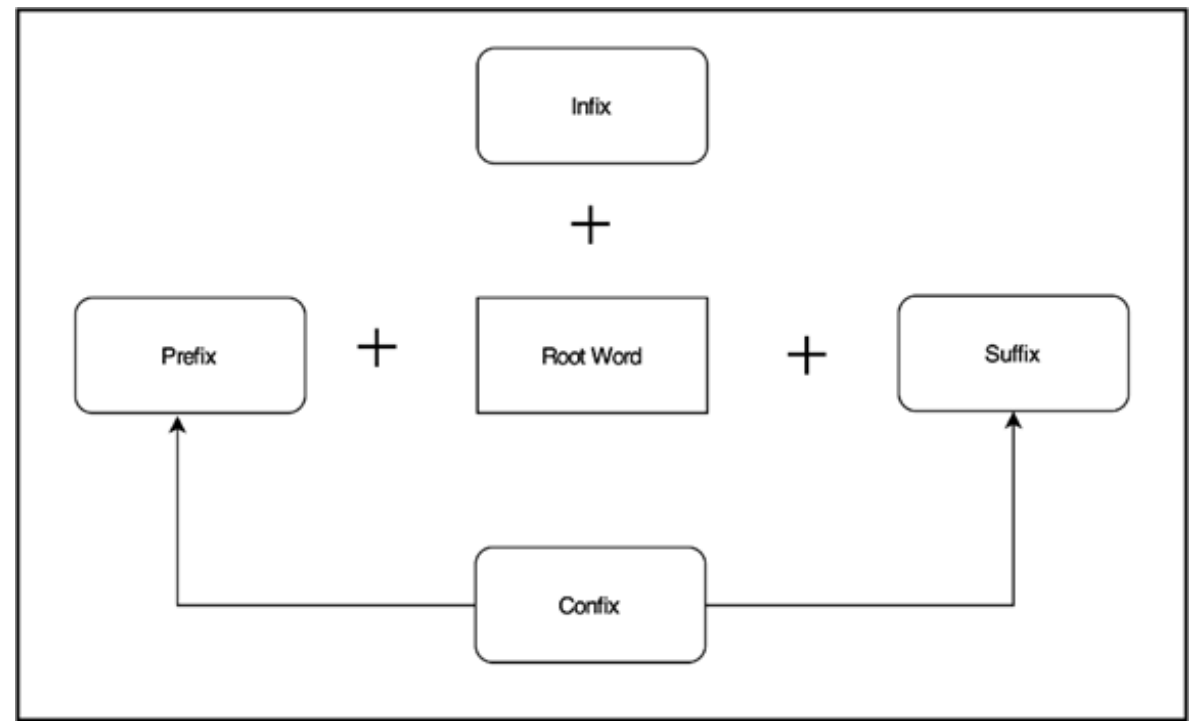

Gambar 2. Konsep Imbuhan Bahasa Indonesia

a. Prefix

Prefix adalah imbuhan yang ditambahkan ke awal kata untuk membentuk kata yang baru. Menurut S. Takdir Alisjahbana dalam Khotimah awalah di-, ke-, ter- memiliki fungsi dalam menyatakan tempat dalam bentuk pasif [7]. Contoh ke- (kedepan), ter- (terdeteksi), di(diakses), dan lain-lain.

b. Suffix

Suffix adalah imbuhan yang diletakkan pada belakang kata dasar [7]. Ada tiga jenis suffix yaitu -kan, -an, -i. Contoh kata yaitu -kan (tawarkan), -an (makanan), -i (manusiawi), akhiran wi dalam kata manusiawi merupakan bunyi dari suffix $-i$.

c. Infix

Infix merupakan imbuhan yang diletakkan pada kata dasar [7]. -em (gemetar), -er (gerigi), el (gelembung).

d. Confix

Confix adalah imbuhan yang diletakkan pada awal dan akhir sebuah kata. Contoh me-kan (merahasiakan), per-an (perkuliahan), dan ber-an (berpakaian).

\subsection{Algoritma Jaro-Winkler Distance}

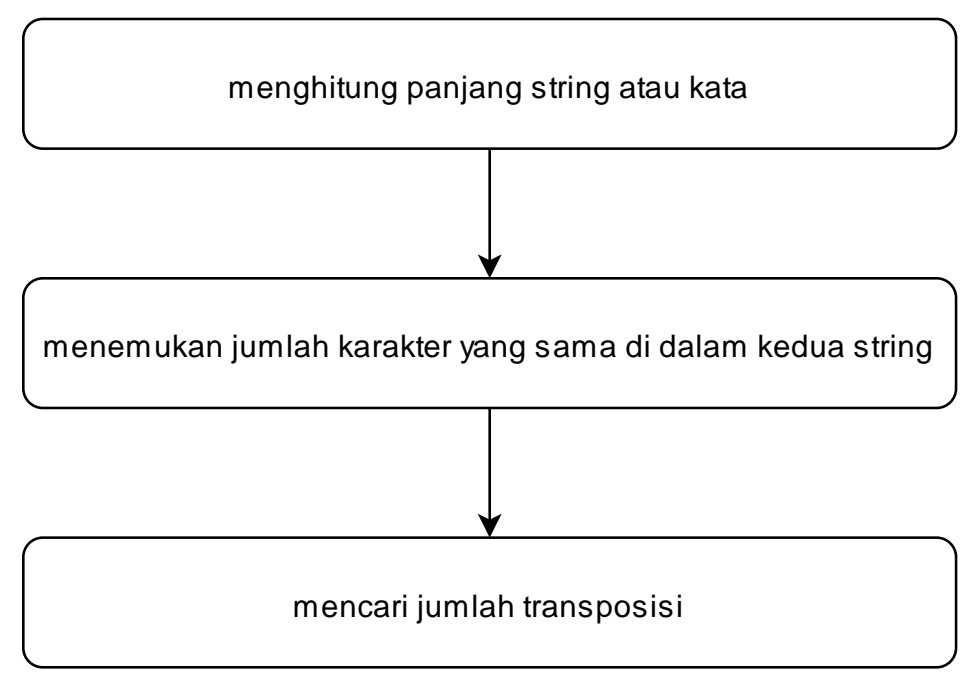

Gambar 3. Komponen Dasar Algoritma Jaro-Winkler Distance 
Algoritma Jaro-Winkler distance adalah algoritma yang menghitung kesamaan antara dua string [8]. Semakin tinggin nilai Jaro-Winkler distance untuk kedua string maka semakin tinggi tingkat kemiripan kedua string tersebut. Nilai normalnya adalah 0 menandakan tidak ada persamaan dan nilai 1 untuk menandakan adanya kesamaan [9]. Algoritma Jaro-Winkler distance memiliki tiga komponen dasar ditunjukkan oleh Gambar 3.

Pada algoritma Jaro-Winkler distance, jarak antara dua kata dihitung dengan menggunakan persamaan (1).

$$
\operatorname{Jaro}(s 1, s 2)=\frac{1}{3}\left(\frac{m}{|s 1|}+\frac{m}{|s 2|}+\frac{m-t}{m}\right)
$$

Nilai $m$ merupakan jumlah karakter yang dari kedua string. Suatu karakter dapat dikatatakan memiliki kesamaan jika memiliki jarak teoritis yang tidak melebihi persamaan (2). $s 1$ merupakan panjang string pertama, sedangkan $s 2$ merupakan panjang string kedua dan $t$ merupakan jumlah trasposisi atau jumlah string yang tertukar posisi.

$$
\left[\frac{\max (|s 1|,|s 2|)}{2}\right]-1
$$

Jaro-Winkler distance menggunakan prefix scale ( $p$ ) yang memberikan tingkat peniliaian yang lebih, dan prefix length (l) yang menyatakan panjang awalan yaitu panjang karakter string yang dibandingkan sampai ditemukannya ketidaksamaan. Apabila string $s 1$ dan $s 2$ dibandingkan maka Jaro-Winkler distance-nya $\left(d_{w}\right)$ dirumuskan persamaan (3).

$$
d_{w}=d_{j}+\left(l * p\left(1-d_{j}\right)\right)
$$

Dimana $d_{w}$ merupakan nilai Jaro-Winkler distance $d_{j}$ adalah nilai Jaro-Winkler distance antara kedua. String $l$ menunjukkan panjang prefix umum di awal string, dimana nilai maksimalnya adalah 4 karakter atau panjang karakter yang sama sebelum ditemukan perbedaan. Sedangkan $p$ adalah konstanta scaling factor. Nilai standar pada konstanta ini menurut winkler adlah $0,1[10]$.

\subsubsection{Contoh Perhitungan Algoritma Jaro-Winkler Distance}

Pada contoh perhitungan berikut ini diambil dari penelitain Prasetyo [11], misalkan pengguna ingin menulis kata "tidur", namun terjadi kesalahan ketik sehingga tertulis kata "tdyr". Pada kasus ini akan dilakukan perhitungan kedekatan jarak kata "tdyr" dengan semua kata yang jumlah karakternya empat sampai enam karakter pada database. Contoh kata "tidak", "tiban”, "tidur".

Perhitungan jarak kedekatan kata antara kata "tdyr" dengan "tiban” menggunakan algoritma Jaro-Winkler distance.

$$
\begin{aligned}
& \operatorname{Jaro}(s 1, s 2)=\frac{1}{3}\left(\frac{m}{|s 1|}+\frac{m}{|s 2|}+\frac{m-t}{m}\right) \\
& \operatorname{string} 1(s 1)=\text { tidyr } \\
& \text { string } 2(s 2)=\text { tiban } \\
& \text { Jumlah karakter string } 1(s 1)=5 \\
& \text { Jumlah karakter string } 2(s 2)=5
\end{aligned}
$$$$
\text { Jumlah karakter } s 1 \text { cocok dengan } s 2(m)=2
$$$$
\text { Jumlah transposisi }(t)=0
$$ 
Citec Journal, Vol. 5, No. 4, Agustus 2018 - Oktober 2018

ISSN: 2460-4259

$\operatorname{Jaro}(s 1)(s 2)=\frac{1}{3}\left(\frac{2}{5}+\frac{2}{5}+\frac{2-0}{2}\right)$

$\operatorname{Jaro}(s 1)(s 2)=0,6$

$\operatorname{Jaro}-\operatorname{Winkler}(s 1)(s 2)=\operatorname{Jaro}(s 1, s 2)+(L * p(1-\operatorname{jaro}(s 1, s 2))$

Kesamaan awal $(L)=2$

Faktor Penskalaran $(p)=0,1$

Jaro $-\operatorname{Winklar}(s 1, s 2)=0,6+(2 * 0,1(1-0,6))$

Jaro $-\operatorname{Winklar}(s 1, s 2)=0,68$

Sehingga dapat diketahui hasil perhitungan pada tabel 1.

Tabel 1. Analisis Komputasi

\begin{tabular}{|c|c|c|c|}
\hline No & String 1 & String 2 & Nilai Jaro-Winkler \\
\hline 1 & Tidyr & tiban & 0.68 \\
\hline 2 & Tidyr & tidur & 0.906 \\
\hline 3 & Tidyr & tidak & 0.813 \\
\hline
\end{tabular}

Dari hasil perhitungan di atas "tidyr" memiliki kemiripan karakter paling dekat dengan kata "tidur” dengan nilai Jaro-Winkler 0.906.

\subsection{Data Kata Berimbuhan Tidak Baku}

Bahasa indonesia terdiri dari dua jenis kata, yaitu kata baku dan tidak baku. Kata baku biasanya digunakan pada sesuatu yang bersifat formal seperti penulisan jurnal, laporan peneletian, dan lain sebagainya. Sedangkan kata tidak baku digunakan pada suasana tidak formal, misalnya berbicara santai dengan teman dekat, chatting, komentar atau posting di media sosial, dan yang lainnya. Pada penelitian ini akan digunakan data kata imbuhan tidak baku bahasa indonesia yang diambil dari penelitan Rahardyan [2] dengan jumlah data yaitu 60 kata imbuhan tidak baku yang dapat dilihat pada Tabel 2.

Tabel 2. Kata Imbuhan Tidak Baku Bahasa Indonesia

\begin{tabular}{|c|l|l|}
\hline No & Kata Dasar & Bentuk Tidak Baku \\
\hline 1 & Terjang & nerjang \\
\hline 2 & Tuduh & nuduh \\
\hline 3 & Terima & nerima \\
\hline 4 & Tegur & negur \\
\hline 5 & pukul & mukul \\
\hline 6 & pimpin & mimpin \\
\hline 7 & coba & nyoba \\
\hline 8 & siram & nyiram \\
\hline 9 & suruh & nyuruh \\
\hline 10 & simpan & nyimpen \\
\hline 11 & sebrang & nyebrang \\
\hline 12 & anggap & nganggep \\
\hline 13 & amuk & ngamuk \\
\hline 14 & ambil & ngambil \\
\hline 15 & buka & ngebuka \\
\hline 16 & bantu & ngebantu \\
\hline
\end{tabular}




\begin{tabular}{|c|c|c|}
\hline No & Kata Dasar & Bentuk Tidak Baku \\
\hline 17 & lepas & ngelepas \\
\hline 18 & bayang & kebayang \\
\hline 19 & injak & keinjek \\
\hline 20 & kabul & kekabul \\
\hline 21 & pergok & kepergok \\
\hline 22 & tipu & ketipu \\
\hline 23 & ulang & keulang \\
\hline 24 & wujud & kewujud \\
\hline 25 & cerita & critain \\
\hline 26 & betul & betulin \\
\hline 27 & manja & manjain \\
\hline 28 & ganggu & gangguin \\
\hline 29 & ganti & gantian \\
\hline 30 & ikut & ikutan \\
\hline 31 & musuh & musuhan \\
\hline 32 & sabun & sabunan \\
\hline 33 & teman & temenan \\
\hline 34 & tukar & tukeran \\
\hline 35 & tanya & nanyain \\
\hline 36 & tunjuk & nunjukin \\
\hline 37 & penting & mentingin \\
\hline 38 & pegang & megangin \\
\hline 39 & selamat & nyelametin \\
\hline 40 & sempat & nyempetin \\
\hline 41 & korban & ngorbanin \\
\hline 42 & hadap & ngadepin \\
\hline 43 & Bukti & ngebuktiin \\
\hline 44 & warna & ngewarnain \\
\hline 45 & dengar & kedengeran \\
\hline 46 & ketemu & ketemuan \\
\hline 47 & benar & beneran \\
\hline 48 & begini & ginian \\
\hline 49 & kawin & kawinan \\
\hline 50 & main & mainan \\
\hline 51 & parkir & parkiran \\
\hline 52 & dulu & duluan \\
\hline 53 & gendut & gendutan \\
\hline 54 & karat & karatan \\
\hline 55 & paling & palingan \\
\hline 56 & sabar & sabaran \\
\hline 57 & bagus & kebagusan \\
\hline 58 & sana & sanaan \\
\hline 59 & cepat & cepetan \\
\hline 60 & pagi & sepagian \\
\hline
\end{tabular}


Citec Journal, Vol. 5, No. 4, Agustus 2018 - Oktober 2018

\section{HASIL DAN PEMBAHASAN}

Pada penelitian ini dilakukan pengukuran tingkat akurasi algoritma Jaro-Winkler distance dalam melakukan stemming kata imbuhan tidak baku bahasa indonesia. Algoritma Jaro-Winkler distance diterapkan pada bahasa pemrograman PHP. Kata imbuhan tidak baku di input kan ke aplikasi, kemudian setiap kata akan di stemming satu persatu. Hasil stemming akan masukkan ke Tabel 3 berikut ini.

Tabel 3. Hasil Stemming Algoritma Jaro-Winkler distance

\begin{tabular}{|c|l|l|l|}
\hline No & Kata Dasar & Bentuk Tidak Baku & Stemming Jaro-Winkler distance \\
\hline 1 & terjang & nerjang & terjang \\
\hline 2 & tuduh & nuduh & tuduh \\
\hline 3 & terima & nerima & terima \\
\hline 4 & tegur & negur & tegur \\
\hline 5 & pukul & mukul & pukul \\
\hline 6 & pimpin & mimpin & pimpin \\
\hline 7 & coba & nyoba & coba \\
\hline 8 & siram & nyiram & siram \\
\hline 9 & suruh & nyuruh & suruh \\
\hline 10 & simpan & nyimpen & pimpin \\
\hline 11 & sebrang & nyebrang & sebrang \\
\hline 12 & anggap & nganggep & pegang \\
\hline 13 & amuk & ngamuk & amuk \\
\hline 14 & ambil & ngambil & ambil \\
\hline 15 & buka & ngebuka & ngebuka \\
\hline 16 & bantu & ngebantu & ngebantu \\
\hline 17 & lepas & ngelepas & ngelepas \\
\hline 18 & bayang & kebayang & bayang \\
\hline 19 & injak & keinjek & injak \\
\hline 20 & kabul & kekabul & kabul \\
\hline 21 & pergok & kepergok & pergok \\
\hline 22 & tipu & ketipu & tipu \\
\hline 23 & ulang & keulang & ulan \\
\hline 24 & wujud & kewujud & wujud \\
\hline 25 & cerita & critain & cerita \\
\hline 26 & betul & betulin & betul \\
\hline 27 & manja & manjain & manja \\
\hline 28 & ganggu & gangguin & ganggu \\
\hline 29 & ganti & gantian & ganti \\
\hline 30 & ikut & ikutan & ikut \\
\hline 31 & musuh & musuhan & musuh \\
\hline 32 & sabun & sabunan & sabun \\
\hline 33 & teman & temenan & teman \\
\hline 34 & tukar & tukeran & tukar \\
\hline 35 & tanya & nanyain & tanya \\
\hline 36 & tunjuk & nunjukin & tunjuk \\
\hline 37 & penting & mentingin & penting \\
\hline 38 & pegang & megangin & pegang \\
\hline 39 & selamat & nyelametin & selamat \\
\hline 40 & sempat & nyempetin & pimpin \\
\hline 41 & korban & ngorbanin & korban \\
\hline & & & \\
\hline
\end{tabular}




\begin{tabular}{|l|l|l|l|}
\hline No & Kata Dasar & Bentuk Tidak Baku & Stemming Jaro-Winkler distance \\
\hline 42 & hadap & ngadepin & ngadepin \\
\hline 43 & bukti & ngebuktiin & ngebuktiin \\
\hline 44 & warna & ngewarnain & ngewarnain \\
\hline 45 & dengar & kedengeran & dengar \\
\hline 46 & ketemu & ketemuan & ketemu \\
\hline 47 & benar & beneran & beneran \\
\hline 48 & begini & ginian & begini \\
\hline 49 & kawin & kawinan & kawin \\
\hline 50 & main & mainan & main \\
\hline 51 & parkir & parkiran & parkir \\
\hline 52 & dulu & duluan & dulu \\
\hline 53 & gendut & gendutan & gendut \\
\hline 54 & karat & karatan & karat \\
\hline 55 & paling & palingan & paling \\
\hline 56 & sabar & sabaran & sabar \\
\hline 57 & bagus & kebagusan & bagus \\
\hline 58 & sana & sanaan & sana \\
\hline 59 & cepat & cepetan & cepat \\
\hline 60 & pagi & sepagian & pagi \\
\hline
\end{tabular}

Berdasarkan hasil pengujian pada Tabel 3 dengan pendekatan similiarity menggunakan algoritma Jaro-Winkler Distance diketahui bahwa tingkat akurasi 85\% atau 51 kata berhasil distemming (3 overstemming, 6 unstemming, 0 understemming).

\section{KESIMPULAN}

Berdasarkan hasil analisis dan pengujian maka dapat ditarik kesimpulan bahwa stemming kata berimbuhan tidak baku bahasa indonesia menggunakan algoritma Jaro-Winkler distance, menghasilkan tingkat akurasi yang cukup baik yaitu sebesar $85 \%$ atau berhasil melakukan stemming sebanyak 51 kata (3 overstemming, 6 unstemming, 0 understemming) dari 60 kata yang digunakan sebagai data pengujian.

\section{SARAN}

Dalam penelitian ini ditemukan 9 kata yang tidak berhasil di-stemming menggunakan algoritma Jaro-Winkler distance. Oleh karena itu untuk penelitian selanjutnya penulis menyarankan untuk melakukan kombinasi beberapa algoritma seperti algoritma Nazief \& Adriani untuk menghasilkan tingkat akurasi yang lebih baik.

\section{UCAPAN TERIMA KASIH}

Penulis mengucapkan terima kasih kepada dosen pembimbing yang telah memberi bimbingan dan terima kasih kepada teman saya Azi karena sudah membatu terhadap penelitian ini. 


\section{DAFTAR PUSTAKA}

[1] Nursyamsi, 2016, Kesalahan Penulisan Kata Bahasa Indonesia, Jurnal Ilmiah Sains dan Teknologi, No. 2, Vol. 15.

[2] Putra, R. B. S., Utami, E., Raharjo, S., 2018, Optimalisasi Stemming Kata Berimbuhan Tidak Baku Pada Bahasa Indonesia Dengan Levenshtein Distance, Jurnal. Pengemb. IT, No. 2, Vol. 03, Hal. 200-205.

[3] Rizki, A. S., Tjahyanto, A., Trialih, R., 2019, Comparison of stemming algorithms on Indonesian text processing, TELKOMNIKA, No. 1, Vol. 17, Hal. 95-103.

[4] Putra, R. B, S., Utami, E., 2018, Non-formal Affixed Word Stemming in Indonesian Language, ICOIACT 2018, Yogyakarta, 6-7 Maret.

[5] Setiawan, R., Kurniawan, A., Budiharto, W., Kartowisastro, I. H., Prabowo, H., 2016, Flexible Affix Classification for Stemming Indonesian Language, 13th International Conference on Electrical Engineering/Electronics, Computer, Telecommunications and Information Technology (ECTI-CON), Chiang Mai, 28 Juni-1 Juli.

[6] Aulia, A., Khairani, D., Hakiem, N., 2017, Development of a Retrieval System for Al Hadith in Bahasa (Case Study: Hadith Bukhari), 5th International Conference on Cyber and IT Service Management (CITSM), Bali, 8-10 Agustus.

[7] Khotimah, K., 2012, Analysis of Indonesia Affixes in English Words Found in Mobile Guide Edition, LANTERN Jurnal, No. 2, Vol. 1, 54-59.

[8] Novantara, P., Pasruli, O., 2017, Implementasi Algoritma Jaro-Winkler Distance Untuk Sistem Pendeteksi Plagiarisme Pada Dokumen Skripsi, Jurnal Buffer Informatika, No 2, Vol. 3.

[9] A. Kornain, F. Yansen, and Tinaliah, 2014, Penerapan Algoritma Jaro-Winkler Distance untuk Sistem Pendeteksi Plagiarisme pada Dokumen Teks Berbahasa Indonesia, SPHPILKOM, pp. 1-9.

[10] A. P. Sari, R. Saptono, and E. Suryani, 2018, The Implementation of Jaro-Winkler Distance and Naive Bayes Classifier for Identification System of Pests and Diseases on Paddy, vol. 7, no. 1, hal 1-7.

[11] A. Prasetyo, W. M. Baihaqi, and I. S. Had, 2018, Algoritma Jaro-Winkler Distance: Fitur Autocorrect dan Spelling Suggestion Pada Penulisan Naskah Bahasa Indonesia di BMS TV, Jurnal Teknologi Informasi dan Ilmu Komputer, vol. 5, hal 435-444. 